\title{
ARCHITECTURE AND RELEVANCE OF SEVERAL STRONGLY ADHERED BIOFILMS OVER A POLYESTER IMIDE (PEI) SURFACE
}

\author{
Giancarlo Soncini-Júnior*; Sandra Mara Martins Franchetti; José Carlos Marconato \\ Departamento de Bioquímica e Microbiologia, Universidade Estadual Paulista, Rio Claro, SP, Brasil.
}

\begin{abstract}
This paper corresponds to an "extended abstract" selected for oral presentation in the $22^{\text {nd }}$ Brazilian Congress of Microbiology, held in Florianópolis, SC, Brazil, in November 17-20, 2003
\end{abstract}

\begin{abstract}
A microscopical study was undertaken to analyze the eventual fungi adhesion over a polyester imide surface in enameled copper wires. Scanning electron microscopy allowed to observe in these adhered biofilms, a high amount of pigments, hyphae and its enzymatic arsenal probably acting in the surface of the polymer. Due to the highly aromatic nature of this polyester and the residual phenol derivates still present in the reticulated polymer, an antifungal activity could be expected, but no significant changes were noted in fungal growing and in the adhesion process. Additionally, the wires showed completely failure in all insulation properties. The studies aimed to understand and evaluate the great fungi potential that could be explored in biodeterioration and biodegradation processes.
\end{abstract}

Key words: fungi, biofilms, hyphae, pigments, adhesion, scanning electron microscopy, polymeric surface, polyester-imide, enameled copper wires.

\section{INTRODUCTION}

Organisms commonly known as fungi have been recognized for their utility in developing and testing many kinds of hypotheses, as model systems in biology, and as creatures of pure beauty and delight. The exploitation of fungi by man is not a recent phenomenon. On the contrary, numerous examples are known which indicate that man has been aware of the value of fungi since the dawn of civilization (1).

Conidia of most filamentous fungi germinate when moisture and nutrients are introduced into the environment, although other factors such as heat, light, and elimination of germination inhibitors can also influence the process. Polymers are very hydrophobic and possess a high molecular weight, what makes significantly difficult the enzymatic processes (3).

The fungi are heterotrophs and exhibit absorptive nutrition. In the filamentous fungi, growth is restricted to the apical region of the filament such that cells produced in previous generations which are now situated in a subapical position do not contribute to growth (4). In some species, it is possible to observe some structures called appresoria, a flat swelling that forms on the end of a vegetative fungal hypha and which adheres to the surface before penetrating it. It was found a key gene that allows fungi to stick to plastic surfaces and form thin coatings called biofilms. The gene, called FLO11, is required for fungal biofilm formation. Biofilms are composed of an exopolymeric matrix and multiple layers of microbial cells leading to the creation of physical barriers and the establishment of chemical gradients. Matrix polymers of biofilms are primarily exopolysaccharides and many of them are negatively charged. Smaller amounts of proteins, nucleic acids and various other components may also be present. However, much of the the biofilm matrix - up to $97 \%$ - is water (2).

Polyester Imides, a thermal resistant class of polymers with important application as electrical insulators, has its resistance against the microorganisms few studied. These polyesters (olygomers with molecular masses below $2.000 \mathrm{~g} \mathrm{~mol}^{-1}$ ) are

*Corresponding author. Mailing address: Departamento de Bioquímica e Microbiologia, Universidade Estadual Paulista. Avenida 24A, 1515, CP 199. 13506-900, Rio Claro, SP, Brasil. E-mail: simcachambord@ig.com.br 
synthesized by the esterification of terephthalic acid and derivates with bi and tri functional glycols. Polyester-imide are dissolved in a mixing of aromatics and some phenol derivates solvents between 25 to $45 \%$ non volatiles, depending on the viscosity of the final varnishes.

These studies aimed to evaluate the great fungi potential present in biodeterioration and biodegradation processes, based on the presence of a strongly adhered biofilm investigated by scanning electron microscopy.

\section{MATERIALS AND METHODS}

A Polyester Imide (PEI) of molecular weight nearly 1,500 g $\mathrm{mol}^{-1}$ was synthesized in a 3.0 liters glass kettle. The copper wires (24 AWG) were enameled in a horizontal enameling machine. During the cure process, the polymer achieves a not determinable degree of polymerization. After the enameling procedure, several samples of 4.5 meters length were took and conduced to the laboratory. A model was developed for studying fungal biofilms in vitro. It involves growing adherent populations on the surface of an enameled polyester imide copper wire coil $(4.5 \mathrm{~m})$ introduced in both Sabouraud and Malt modified Sabouraud media. Growth was monitored daily, and can be visualized by Scanning Electron Microscopy - Digital Scanning Microscopy DSM 940 A - Zeiss Germany.

\section{RESULTS AND DISCUSSION}

Due to the highly aromatic nature of the polyester imide and also a residual phenol derivates still present in the reticulated polymer, an antifungal activity could be expected, but no significant changes were noted indeed in the fungal growing.

Fig. 1 shows the enameled polyester imide copper kept in Sabouraud Malt modified medium for 2 months at $32^{\circ} \mathrm{C}$, but with no inoculations.

The following figures, show a very interesting situation. Much like a lock and key, adhesins (the key), which are surface proteins on the outer membrane or cell wall of fungi, recognize only particular molecular conformations and bind to specific, complementary receptors (the lock) on the surface. These adhesins are also required for the formation of fungal biofilms, a multicellular aggregate of microorganisms that can adhere to inert surfaces. The exopolymers formed are so adhered to the surface of the polymer that, even with boiling water, they were not totally removed, proposing these mechanisms related above.

Characteristic pigments were produced by a wide variety of fungi. These pigments are directly involved in biodeterioration of the surface. The surface quality is unacceptable and the wires exhibited a completely failure in all insulating properties, mainly due to the presence of several lacks in the surface of the polymer. The fungal growing in the above mentioned solids medium containing enameled wires was very intense and the whole polymer surface was dominated by several hyphae. Even with boiling water, these biofilms were not totally removed from the wires. To some extent, they may constitute a contribution to our knowledge of the great fungal potential that could be explored in biodeterioration and biodegradation processes. In conclusion, further investigations of enzymatic and surface interactions by fungal biofilms are still necessary.

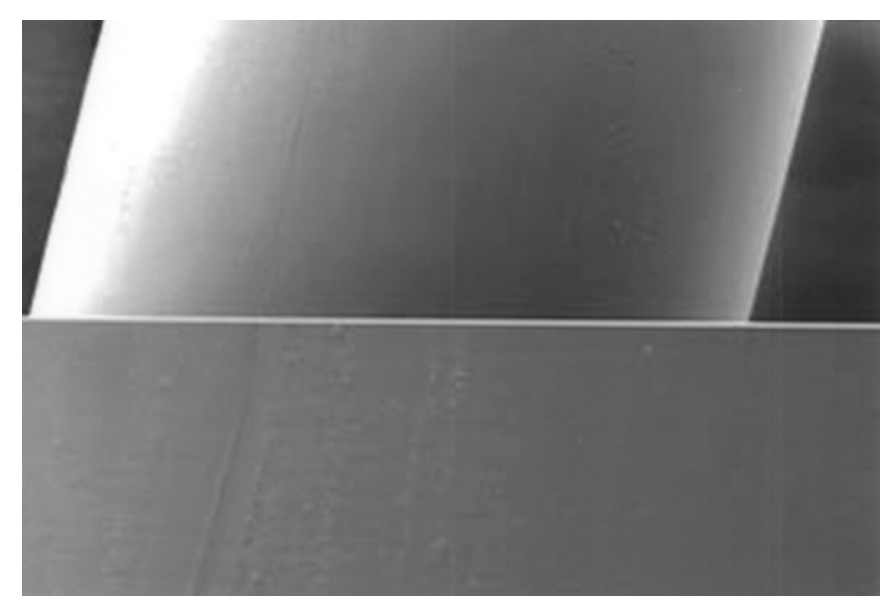

Figure 1. Fragment of an enameled polyester imide copper wire kept for 2 months at $32^{\circ} \mathrm{C}$ in a Malt Sabouraud modified medium, showing a good and smooth polymer surface. Scanning Electron Microscopic (Digital Scanning Microscopy DSM 940 A - Zeiss Germany). Original magnification about x125 (above) and x500 (below).

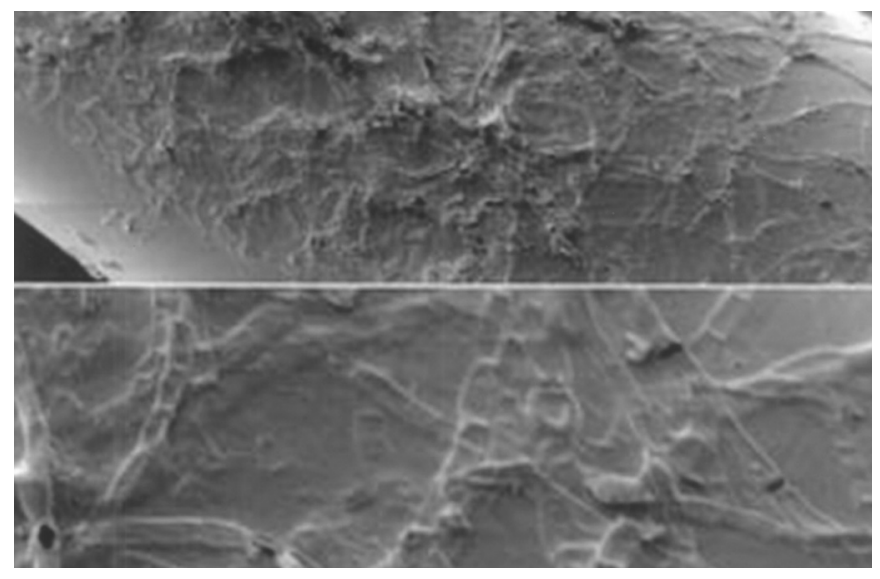

Figure 2. Fragment of an enameled polyester imide copper wire kept for 2 months at $32^{\circ} \mathrm{C}$ in a Malt Sabouraud modified medium, biotreated with Curvularia geniculata showing a strongly adhered biofilm, pigments and septate hyphae. Scanning Electron Microscopic (Digital Scanning Microscopy DSM 940 A - Zeiss Germany). Original magnification about x125 (above) and x500 (below). 


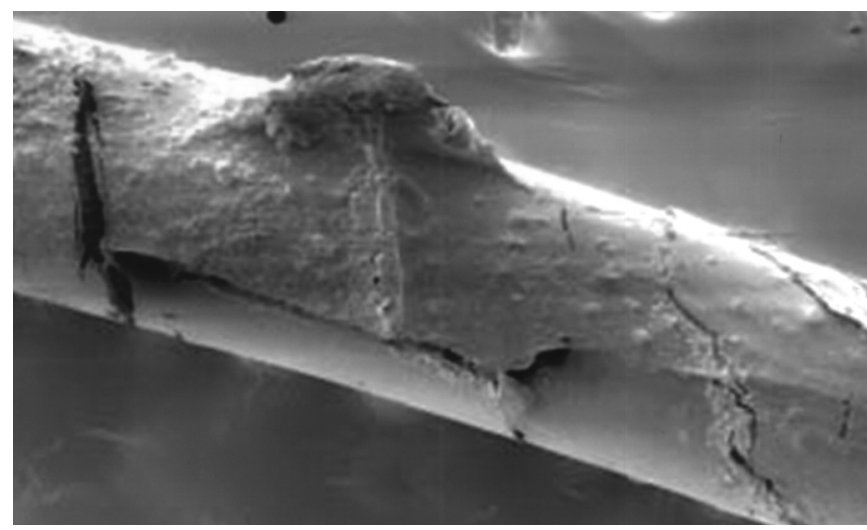

Figure 3. Fragment of an enameled polyester imide copper wire kept for 2 months at $32^{\circ} \mathrm{C}$ in a Malt Sabouraud modified medium, biotreated with Aspergillus fumigatus, showing a strongly adhered biofilm and several cracks in the polymer surface. Scanning Electron Microscopic (Digital Scanning Microscopy DSM 940 A-Zeiss Germany). Original magnification about x125.

\section{RESUMO}

\section{Arquitetura e relevância de diversos biofilmes fortemente aderidos a uma superfície de poliéster-imida}

Um estudo microscópico foi considerado para analisar a eventual adesão de fungos sobre uma superfície de poliésterimida presente em fios de cobre esmaltados. A microscopia eletrônica de varredura, permitiu observar nestes biofilmes aderidos, uma alta quantidade de pigmentos, hifas e um arsenal enzimático possivelmente atuando na superfície desta macromolécula. Devido a natureza altamente aromática deste material e traços de derivados fenólicos usados como solventes - que se fazem ainda presentes no polímero já reticulado, uma certa atividade anti-fúngica poderia ser esperada, todavia não foram observadas alterações no crescimento dos microrganismos, bem como no processo de adesão dos fungos. Adicionalmente a este fato, os fios esmaltados revelaram total descaracterização de suas propriedades isolantes. Os estudos visam compreender e avaliar o grande potencial demonstrado pelos fungos que poderia em caráter vindouro, explorado em processos de biodeterioração e biodegradação

Palavras-chave: fungos, biofilmes, hifas, pigmentos, adesão, microscopia eletrônica de varredura, superfície polimérica, poliéster-imida, fios de cobre esmaltados.

\section{REFERENCES}

1. Alexopoulos, C.J.; Mims, C.W.; Blackwell, M. Introductory Mycology., 4(1):5-28, 1996.

2. Douglas, L.J. Medical Importance of Biofilms in Candida Infections. Rev. Iberoam. Micol., Spain, 19:139-143, 2002.

3. Karlsson, S. et al.Biodegradation of polyethylene and the influence of surfactants. Polymer Degradation and Stability, England, 21:237250, 1988

4. Smith, J.E.; Berry, D.R. An introduction to Biochemistry of Fungal Development - Second Edition, Academic Press Inc, New York, 1976. p. 282-296. 